\title{
Dual-Purpose of the Winged Bean (Psophocarpus tetragonolobus (L.) DC.), the Neglected Tropical Legume, Based on Pod and Tuber Yields
}

\author{
Sasiprapa Sriwichai, Tidarat Monkham, Jirawat Sanitchon, Sanun Jogloy and Sompong Chankaew *D
}

Citation: Sriwichai, S.; Monkham, T.; Sanitchon, J.; Jogloy, S.; Chankaew, S. Dual-Purpose of the Winged Bean (Psophocarpus tetragonolobus (L.) DC.), the Neglected Tropical Legume, Based on Pod and Tuber Yields. Plants 2021, 10, 1746. https://doi.org/ $10.3390 /$ plants10081746

Academic Editors: Milan S. Stankovic, Othmane Merah, Purushothaman Chirakkuzhyil Abhilash and Rodomiro Ortiz

Received: 29 July 2021

Accepted: 20 August 2021

Published: 23 August 2021

Publisher's Note: MDPI stays neutral with regard to jurisdictional claims in published maps and institutional affiliations.

Copyright: (c) 2021 by the authors. Licensee MDPI, Basel, Switzerland. This article is an open access article distributed under the terms and conditions of the Creative Commons Attribution (CC BY) license (https:/ / creativecommons.org/licenses/by/ $4.0 /)$.
Department of Agronomy, Faculty of Agriculture, Khon Kaen University, Khon Kaen 40002, Thailand; sasiprapa.sr@kkumail.com (S.S.); tidamo@kku.ac.th (T.M.); jirawat@kku.ac.th (J.S.); sanun@kku.ac.th (S.J.)

* Correspondence: somchan@kku.ac.th; Tel.: +66-85124-0427

Abstract: Winged beans (Psophocarpus tetragonolobus (L.) DC.) are grown as a vegetable legume crop in Thailand. All parts of the plant, including pods, seeds, leaves, flowers, and tubers are edible and are rich in protein and nutrients. Although the major consumption of winged bean is based on pod and tuber yields, only the people of Myanmar and Indonesia utilize winged bean tubers as food materials. The usefulness of the winged bean as an alternative crop for staple food and feed can shed some light on the impact of winged bean. Therefore, the evaluation of the dual purpose of the winged bean based on pod tuber yields is the objective of this study. In this study, ten-winged bean accessions-six accessions obtained from introduced sources and four accessions obtained from local Thai varieties-were laid out in randomized complete block design (RCBD) with three replications at the Agronomy Field Crop Station, Faculty of Agriculture, Khon Kaen University, Khon Kaen, Thailand from September 2019 to April 2020 and from October 2020 to April 2021. Data, including total pod weight, number of pods, pod length, 10-pod weight, and tuber weight were recorded, and the proximate nutrient and mineral contents in the tubers were also determined. The results revealed that the principal effects of year $(Y)$ and genotype $(G)$ were significant for total pod weight and the number of pods. Moreover, the $Y \times G$ interactions were principal effects upon the total pod weights and tuber weights. The results indicated that superior genotype and appropriate environmental conditions are key elements in successful winged bean production for both pod and tuber yields. The winged bean accessions W099 and W018 were consistent in both experimental years for pod and tuber yields at 23.6 and $18.36 \mathrm{~T} / \mathrm{ha}$ and 15.20 and $15.5 \mathrm{~T} / \mathrm{ha}$, respectively. Each accession also proved high in tuber protein content at $20.92 \%$ and $21.04 \%$, respectively, as well as significant in fiber, energy, and minerals. The results suggest that the winged bean accessions W099 and W018 can be used for dual-purpose winged bean production in Thailand.

Keywords: winged bean; pod yield; tuber weight; nutrient content; protein content

\section{Introduction}

The winged bean (Psophocarpus tetragonolobus (L.) DC.) is an underutilized tropical leguminous species, classified in the family of Fabaceae and subfamily of Papilionoideaeis [1]. Winged bean is an important tropical vegetable legume with high nutritional value [2], that can be grown in humid, tropical countries such as Indonesia, Malaysia, Bangladesh, and Thailand [3,4]. The winged bean can be cultivated in all of Thailand's provinces, and produces edible pods, seeds, leaves, flowers, and tuberous roots that are rich in protein. As a tropical legume, its seeds contain high amounts of protein and oil [5], and it is often referred to as the 'soybean of the tropics' [6,7]. Young pods of the winged bean are consumed in raw, steamed, boiled, stir-fried, or pickled forms. In Southeast Asia, young pods are generally cooked in a variety of ways or consumed as a side dish or salad. In Myanmar, the crop is also popularly grown specifically for its young tuberous roots. The immature pods contain $1 \%$ to $3 \%$ protein, as well as several vitamins and minerals [8]. The 
winged bean's mature seeds contain protein levels of $28 \%$ to $45 \%$ [9], oil of roughly $14 \%$ to $19 \%$, and carbohydrates of $34 \%$ to $40 \%$ [10]. Moreover, its raw tubers contain $12 \%$ to $19 \%$ protein and $1 \%$ to $4 \%$ fat [10].

The immature wing bean pods represent its major form of consumption, as they are rich in minerals and vitamins, particularly vitamin A [11]. In Thailand, the winged bean is an underutilized crop that Thais consume in a variety of ways. Immature pods are used for salads, soups, and direct consumption. Tuber roots are typically roasted or boiled and consumed directly or made into confectionaries. In Thailand, winged beans are generally grown on smaller commercial scales that supply young pods to local markets. The summer market price of winged beans ranges between USD 8 to 10 per $\mathrm{Kg}$. However, while the winged bean has the potential to become an important economic food crop in Thailand, very little research has been conducted on it over the past few decades.

All the winged bean cultivars grown in Thailand are either landraces or selections from landraces. Seeds that growers use for cultivation may also be from other provenances or geographic regions that have perhaps traveled with a farmer's relatives [12]. Additionally, no genetic improvement program for the crop currently exists. Moreover, the yield potential was not evaluated, nor was an assessment of winged bean accessions on commercially desired traits such as pod length, pod tenderness, taste, and pod color, which directly affect consumer preferences.

In the Mandalay region of Myanmar and the Papua province of Indonesia, the tuber of the winged bean represents a staple food, again, due to its high protein contents. The crude protein yield of the winged tuber was estimated to be at least 300 to $600 \mathrm{~kg} / \mathrm{ha}$ [13]. In Thailand, few areas, such as some remote villages in the Photharam district of Ratchaburi province consume the winged bean tuber, as research on it and its consequent popularity have not been established. Furthermore, winged bean research has focused primarily on pod yield only. After the summer's pod production, the winged bean dries up and is removed for the next rotation of crops, such as corn, at which time tubers are discarded and not utilized. Eagleton [13] reported their highest tuber yield at $2629 \mathrm{~kg}$ dry matter/ha, suggesting the necessary utilization of the winged bean's productivity and value. Note that not all accessions can produce tubers. Hildebrand [14] determined that only 38 out of 189 genotypes are capable of producing tubers.

Today's ever-growing global population has increased the demand for animal-sourced feed, particularly in developing countries $[15,16]$. Today's food-feed materials compete worldwide as human food and livestock feed, and commonly contain the same ingredients. Protein and carbohydrate sources, such as maize, cassava, and bean have fueled high feed prices, which in turn has generated new interest in alternative $\mathrm{N}$ sources for livestock feed. Therefore, food-feed production systems must be integrated for livestock-crop production. In this type of crop system, farmers would harvest produce for human consumption, whereas crop residue or byproducts would be utilized as feed for livestock [17]. Recent research on the potential of winged bean production has provided a framework for continued study of the winged bean as an alternative, staple crop for both food and feed, particularly within low input cropping systems of the tropics and subtropics. The objective of this study, therefore, was the evaluation of the dual purpose of the winged bean based on pod tuber yields.

\section{Results}

\subsection{Genotype Response and Environment}

The combined analyses of variance for total pod weight, number of pods, pod length, 10-pod weight, and tuber weight of ten winged bean accessions under two experimental years revealed that the principal effects (year $(Y)$, genotype $(G)$, and $Y \times G$ interaction) were significant (Table 1 ). This experimental year significantly affected the total pod weight and the number of pods with a 95\% confidence level, whereas the genotype effects were statistically significant on the total pod weight, the number of pods, and pod length at a 99\% confidence level. Additionally statistically significant was the $\mathrm{Y} \times \mathrm{G}$ interaction's 
effect on total pod weight and tuber weight at a 95\% confidence level (Table 1). Our results found significant effects upon all traits, except 10-pod weight, due to its uniformity within the marketplace.

Table 1. Mean squares of total pod weights, number of pods, 10-pod weights, pod lengths, and tuber weights of ten accessions evaluated across two years under rainy season conditions at Khon Kaen University in 2019 and 2020.

\begin{tabular}{|c|c|c|c|c|c|c|}
\hline Source of Variation & df & $\begin{array}{c}\text { Total Pod Weight } \\
\text { (T/ha) }\end{array}$ & $\begin{array}{l}\text { Number of Pods } \\
\text { (Pod/ha) }\end{array}$ & $\begin{array}{l}\text { 10-Pod Weight } \\
\text { (g) }\end{array}$ & $\begin{array}{l}\text { Pod Length } \\
\text { (cm) }\end{array}$ & $\begin{array}{c}\text { Tuber Weight } \\
\text { (T/ha) }\end{array}$ \\
\hline Year $(Y)$ & 1 & 207.06 * & $8,162,282$ * & 4.12 & 0.03 & 7.7 \\
\hline Rep. within Y & 4 & 18.55 & 863,650 & 1263.34 & 0.31 & 6.38 \\
\hline Genotypes (G) & 9 & $21.47^{* *}$ & $548,701 * *$ & 1101.94 & $1.33^{* *}$ & 12.68 \\
\hline$Y \times G$ & 9 & $8.95 *$ & 234,256 & 1239.4 & 0.35 & $15.56^{*}$ \\
\hline pool error & 36 & 3.49 & 137,609 & 1117.94 & 0.23 & 7.04 \\
\hline Grand Mean & & 4.83 & 760.67 & 71.93 & 13.81 & 7.33 \\
\hline CV(YearxRep) & & 89.26 & 122.17 & 49.41 & 4.01 & 34.45 \\
\hline CV(YearxRepxVariety) & & 38.71 & 48.77 & 46.48 & 3.49 & 36.19 \\
\hline
\end{tabular}

* Significant at 0.05 probability level. ** Significant at 0.01 probability level.

\subsection{Potential of Pod-Related Traits and Tuber Yield Production of the Winged Bean}

Variations were observed in pod-related traits in both experiment years, except for the 10-pod weights (Table 2). In the 2019 experiment, the pod yields of 10 winged bean accessions ranged from $23.6 \mathrm{~T} / \mathrm{ha}$ (W099) to $5.58 \mathrm{~T} / \mathrm{ha}$ (W077). Four winged bean accession including the W099, W018, W061, and W048 accessions, showed high yields of 23.64, 18.36, 15.82 , and $15.06(\mathrm{~T} / \mathrm{ha})$, respectively. The same accessions also produced a high number of pods. The W099 accession was highest in pod number at up to $39,354 \times 102$ pods/ha (Table 2). The 10-pod weights ranged from 62.97 to $59.85 \mathrm{~g}$, and pod lengths ranged from 14.51 to $13.11 \mathrm{~cm}$ (Table 2). In the 2020 experiment, the W099, W001, W018, and W061 accessions generated the highest pod yields of $11.7,11.18,8.44$, and $6.42 \mathrm{~T} /$ ha, respectively. These same accessions also presented the highest number of pods. Similar to the results of the 2019 experiment, the W099 accession achieved the highest number of pods at up to $15,880 \times 102$ pods/ha (Table 2). The 10-pod weight ranged between 77.89 to $65.15 \mathrm{~g}$, and the pod lengths ranged from 14.54 to $13.06 \mathrm{~cm}$ (Table 2). Our assessment of the pod-related traits indicated that four winged bean accessions (W099, W001, W018, and W061) showed the highest yield performance in pod production.

Table 2. Variability of winged bean total pod weight, number of pods, 10-pod weight, and pod length of ten accessions evaluated across two years under rainy season conditions at Khon Kaen University in 2019 to 2020.

\begin{tabular}{|c|c|c|c|c|c|c|c|c|}
\hline \multirow{2}{*}{ Accessions } & \multicolumn{2}{|c|}{ Total Pod Weight (T/ha) } & \multicolumn{2}{|c|}{ Number of Pods (Pod/ha) } & \multicolumn{2}{|c|}{ 10-Pod Weight (g) } & \multicolumn{2}{|c|}{ Pod Length (cm) } \\
\hline & 2019 & 2020 & 2019 & 2020 & 2019 & 2020 & 2019 & 2020 \\
\hline W001 & $10.94 \mathrm{~b}-\mathrm{d}$ & $11.18 \mathrm{ab}$ & $17,694 \times 10^{2} \mathrm{~b}-\mathrm{d}$ & $14,280 \times 10^{2} \mathrm{ab}$ & 61.84 & 77.16 & $14.11 \mathrm{a}-\mathrm{c}$ & $14.49 \mathrm{ab}$ \\
\hline W005 & $7.22 \mathrm{~cd}$ & $3.96 \mathrm{c}-\mathrm{e}$ & $12,254 \times 10^{2} \mathrm{~cd}$ & $5493 \times 10^{2} \mathrm{c}-\mathrm{e}$ & 62.97 & 68.53 & $13.28 \mathrm{de}$ & $13.18 \mathrm{~cd}$ \\
\hline W005 & $7.22 \mathrm{~cd}$ & $3.96 \mathrm{c}-\mathrm{e}$ & $12,254 \times 10^{2} \mathrm{~cd}$ & $5493 \times 10^{2} \mathrm{c}-\mathrm{e}$ & 62.97 & 68.53 & $13.28 \mathrm{de}$ & $13.18 \mathrm{~cd}$ \\
\hline W007 & $5.58 \mathrm{~d}$ & $6.10 \mathrm{~b}-\mathrm{e}$ & $8954 \times 10^{2} \mathrm{~d}$ & $7447 \times 10^{2} \mathrm{c}-\mathrm{e}$ & 61.76 & 62.79 & $13.93 \mathrm{a}-\mathrm{d}$ & $14.54 \mathrm{a}$ \\
\hline W018 & $18.36 \mathrm{ab}$ & $8.44 \mathrm{a}-\mathrm{c}$ & $32,186 \times 10^{2} \mathrm{ab}$ & $11,367 \times 10^{2} \mathrm{a}-\mathrm{c}$ & 61.84 & 78.52 & 13.32 de & $13.85 \mathrm{a}-\mathrm{d}$ \\
\hline W031 & $12.72 \mathrm{~d}-\mathrm{d}$ & $1.22 \mathrm{e}$ & $20,500 \times 10^{2} \mathrm{~d}-\mathrm{d}$ & $1867 \times 10^{2} \mathrm{e}$ & 64.69 & 66.85 & $14.15 \mathrm{a}-\mathrm{c}$ & $13.19 \mathrm{~cd}$ \\
\hline W048 & $15.06 \mathrm{~b}$ & $2.46 \mathrm{de}$ & $24,114 \times 10^{2} \mathrm{a}-\mathrm{d}$ & $3140 \times 10^{2} \mathrm{de}$ & 65.37 & 69.92 & $14.51 \mathrm{a}$ & $14.00 \mathrm{a}-\mathrm{c}$ \\
\hline W055 & $13.12 \mathrm{bc}$ & $5.02 \mathrm{c}-\mathrm{e}$ & $22,686 \times 10^{2} \mathrm{a}-\mathrm{d}$ & $6107 \times 10^{2} \mathrm{c}-\mathrm{e}$ & 59.85 & 65.15 & $13.63 \mathrm{~b}-\mathrm{e}$ & $13.90 \mathrm{a}-\mathrm{d}$ \\
\hline W061 & $15.82 \mathrm{~b}$ & $6.42 \mathrm{~b}-\mathrm{d}$ & $28,406 \times 10^{2} \mathrm{a}-\mathrm{c}$ & $8833 \times 10^{2} \mathrm{~b}-\mathrm{d}$ & 62.48 & 73.22 & $13.11 \mathrm{e}$ & $13.06 \mathrm{~d}$ \\
\hline W099 & $23.64 \mathrm{a}$ & $11.7 \mathrm{a}$ & $39,354 \times 10^{2} \mathrm{a}$ & $15,880 \times 10^{2} \mathrm{a}$ & 67.43 & 76.68 & $14.40 \mathrm{ab}$ & $14.46 \mathrm{ab}$ \\
\hline W148 & $11.20 \mathrm{~b}-\mathrm{d}$ & $2.86 \mathrm{de}$ & $19,754 \times 10^{2} \mathrm{~b}-\mathrm{d}$ & $3953 \times 10^{2} \mathrm{de}$ & 62.13 & 77.89 & $13.46 \mathrm{c}-\mathrm{e}$ & $13.65 b-d$ \\
\hline Mean & 13.37 & 5.94 & $22,590 \times 10^{2}$ & $7837 \times 10^{2}$ & 63.03 & 71.67 & 13.79 & 13.89 \\
\hline F-test & $* *$ & $* *$ & * & $* *$ & ns & ns & $* *$ & $* *$ \\
\hline $\mathrm{CV}(\%)$ & 32.73 & 49.9 & 43.2 & 49.17 & 5.07 & 15.88 & 3.27 & 3.69 \\
\hline
\end{tabular}

The different letter after mean within column showed significant different. ns Nonsignificant, * Significant at 0.05 probability level, and ** Significant at 0.01 probability level. 
Variations were also observed in tuber yields of both experiment years, in which the winged bean accessions W048, W148, W007, W018, and W099 produced yields greater than $15 \mathrm{~T} /$ ha in the 2019 experiment (Table 3). The 2020 experiment, however, produced lower tuber yields from the W018, W001, and W099 accessions at just over 9 T/ha (Table 3). Only the W018 and W099 accessions were consistent in tuber yield in both experiment years. The W018 and W099 winged bean accessions produced significantly higher pod and tuber yield potentials (Tables 2 and 3), deeming them suitable for dual-purpose winged bean production (Figure 1).

Table 3. Tuber weights of ten winged bean accessions evaluated across two years under rainy season conditions at Khon Kaen University in 2019 and 2020.

\begin{tabular}{ccc}
\hline & \multicolumn{2}{c}{ Tuber Weight (T/ha) } \\
\cline { 2 - 3 } Accessions & 2019 Experiment & 2020 Experiment \\
& $12.00 \mathrm{~b}-\mathrm{d}$ & $10.20 \mathrm{a}$ \\
W001 & $13.54 \mathrm{~b}-\mathrm{d}$ & $4.50 \mathrm{e}$ \\
W005 & $16.46 \mathrm{a}-\mathrm{c}$ & $6.80 \mathrm{~cd}$ \\
W007 & $15.54 \mathrm{a}-\mathrm{c}$ & $10.23 \mathrm{a}$ \\
W031 & $12.2 \mathrm{~b}-\mathrm{d}$ & $8.10 \mathrm{bc}$ \\
W048 & $23.00 \mathrm{a}$ & $5.87 \mathrm{de}$ \\
W055 & $7.96 \mathrm{~cd}$ & $5.90 \mathrm{de}$ \\
W061 & $6.14 \mathrm{~d}$ & $8.13 \mathrm{bc}$ \\
W099 & $15.20 \mathrm{a}-\mathrm{d}$ & $9.07 \mathrm{ab}$ \\
W148 & $17.44 \mathrm{ab}$ & $8.07 \mathrm{bc}$ \\
Mean & 14.00 & 7.69 \\
F-test & $*$ & $* *$ \\
CV $(\%)$ & 37.91 & 12.42 \\
\hline
\end{tabular}

The different letter after mean within column showed significant different. * Significant at 0.05 probability level. ** Significant at 0.01 probability level.
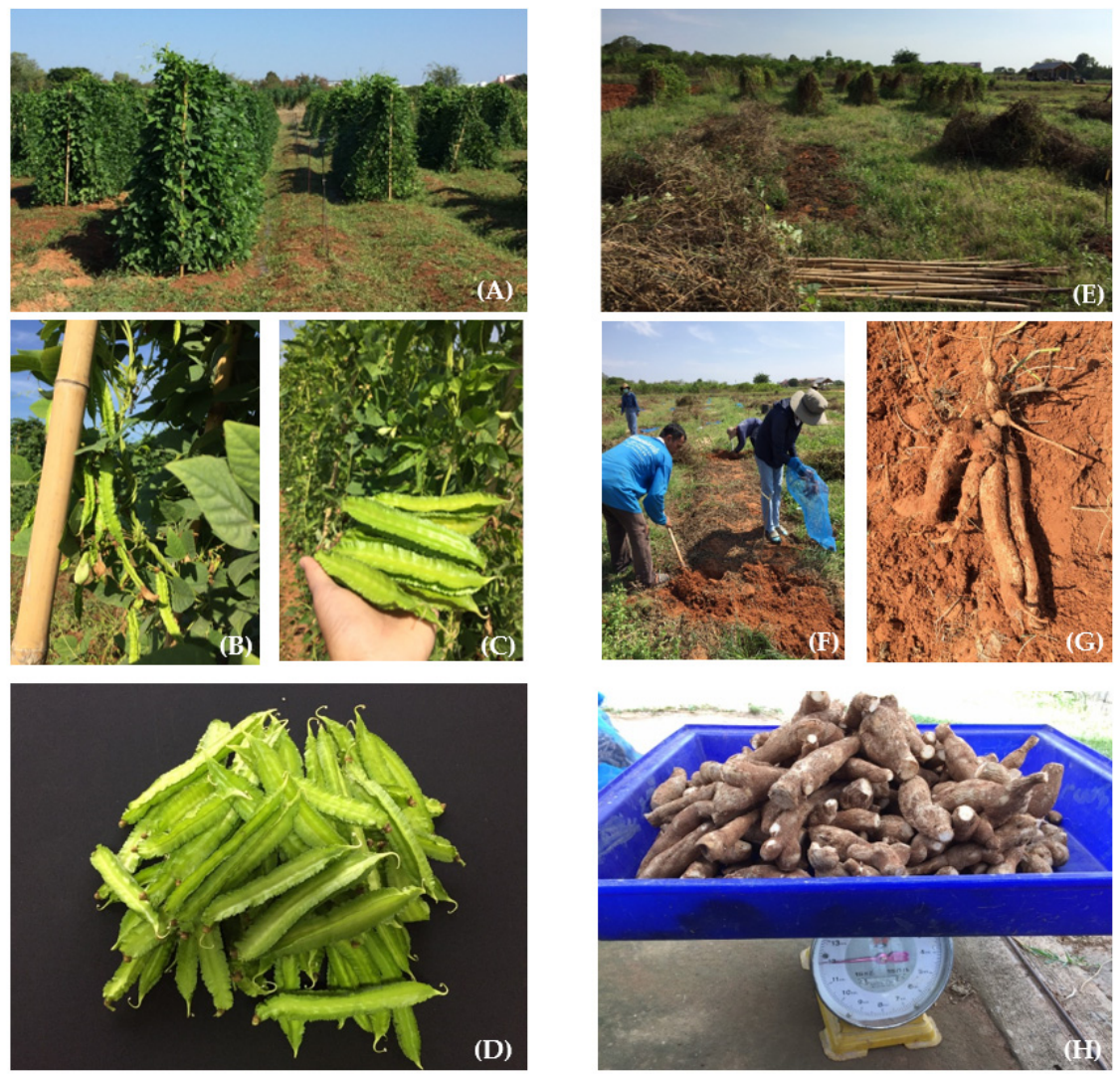

Figure 1. Dual-purpose of the winged bean (Psophocarpus tetragonolobus (L.) DC.) based on pod yield (A-D) and tuber yield $(\mathbf{E}-\mathbf{H})$. 


\subsection{Proximate Analysis of Nutrients and Minerals of Winged Bean Tuber}

The proximate compositions of nutrient and mineral contents in the tuber of each winged bean accession were statistically significant at a 99\% confidence level (Tables 4 and 5): the values of crude fat ranged from $1.13 \%$ (W148) to $0.26 \%$ (W031); the values of crude fiber ranged from $4.07 \%$ (W018) to $2.37 \%$ (W099); the values of neutral detergent fiber ranged from $32.38 \%$ (W061) to $15.29 \%$ (W148); the values of acid detergent fiber ranged from $8.98 \%$ (W018) to $5.77 \%$ (W005); the values of gross energy ranged from $16,241 \mathrm{~g} / \mathrm{J}$ (W005) to $15,810 \mathrm{~g} / \mathrm{J}$ (W099); the values of ash ranged from 3.03\% (W061) to 2.48\% (W005); and the values of crude protein ranged from $25.59 \%$ (W061) to $20.41 \%$ (W005) (Table 4). The results of the proximate composition analysis of winged bean tubers in this study suggests its suitability for consumption or use as an alternative source for animal feed, due to its high protein (up to $25.59 \%$ ) and energy (up to $16,264 \mathrm{~J} / \mathrm{g}$ ) contents (Table 5).

Table 4. Proximate composition of winged bean tubers of ten accessions at Khon Kaen University in the 2019 experiment.

\begin{tabular}{cccccccc}
\hline Accessions & EE (\%) & CF (\%) & NDF (\%) & ADF (\%) & GE (J/g) & Ash (\%) & CP (\%) \\
\hline W001 & $0.29 \mathrm{ef}$ & $3.20 \mathrm{c}$ & $21.68 \mathrm{~g}$ & $6.24 \mathrm{e}$ & $16,174 \mathrm{ab}$ & $2.96 \mathrm{~b}$ & $21.66 \mathrm{c}$ \\
W005 & $0.33 \mathrm{~d}$ & $3.11 \mathrm{~cd}$ & $24.46 \mathrm{~d}$ & $5.77 \mathrm{~g}$ & $16,241 \mathrm{a}$ & $2.48 \mathrm{e}$ & $20.41 \mathrm{e}$ \\
W007 & $0.32 \mathrm{de}$ & $3.57 \mathrm{~b}$ & $21.66 \mathrm{~g}$ & $6.54 \mathrm{~d}$ & $16,157 \mathrm{a}-\mathrm{c}$ & $2.85 \mathrm{c}$ & $21.68 \mathrm{c}$ \\
W018 & $0.31 \mathrm{de}$ & $4.07 \mathrm{a}$ & $22.91 \mathrm{f}$ & $8.98 \mathrm{a}$ & $15,990 \mathrm{~cd}$ & $3.01 \mathrm{ab}$ & $21.04 \mathrm{~d}$ \\
W031 & $0.26 \mathrm{f}$ & $2.99 \mathrm{~d}$ & $26.90 \mathrm{~b}$ & $7.11 \mathrm{c}$ & $16,132 \mathrm{a}-\mathrm{c}$ & $2.98 \mathrm{ab}$ & $22.11 \mathrm{~b}$ \\
W048 & $0.85 \mathrm{~b}$ & $2.60 \mathrm{f}$ & $26.21 \mathrm{c}$ & $6.48 \mathrm{~d}$ & $15,869 \mathrm{de}$ & $2.68 \mathrm{~d}$ & $21.48 \mathrm{c}$ \\
W055 & $0.88 \mathrm{~b}$ & $3.02 \mathrm{~d}$ & $16.62 \mathrm{~h}$ & $7.00 \mathrm{c}$ & $15,845 \mathrm{de}$ & $2.85 \mathrm{c}$ & $20.71 \mathrm{de}$ \\
W061 & $0.63 \mathrm{c}$ & $2.96 \mathrm{de}$ & $32.38 \mathrm{a}$ & $7.33 \mathrm{~b}$ & $16,264 \mathrm{a}$ & $3.03 \mathrm{a}$ & $25.59 \mathrm{a}$ \\
W099 & $1.13 \mathrm{a}$ & $2.37 \mathrm{~g}$ & $24.20 \mathrm{e}$ & $5.92 \mathrm{f}$ & $15,810 \mathrm{e}$ & $2.62 \mathrm{~d}$ & $20.92 \mathrm{~d}$ \\
W148 & $1.16 \mathrm{a}$ & $2.82 \mathrm{e}$ & $15.29 \mathrm{i}$ & $6.03 \mathrm{f}$ & $16,050 \mathrm{bc}$ & $2.62 \mathrm{~d}$ & $20.73 \mathrm{de}$ \\
\hline F-test & $* *$ & $* *$ & $* *$ & $* *$ & $* *$ & $*$ & $* *$ \\
\hline CV (\%) & 2.75 & 2.26 & 0.44 & 0.81 & 0.49 & 0.59 & 0.72 \\
\hline
\end{tabular}

The different letter after mean within column showed significant different. ${ }^{* *}$ Significant at 0.01 probability level $\mathrm{EE}=$ ether extract (crude fat), $\mathrm{CF}=$ crude fiber, $\mathrm{NDF}=$ neutral detergent fiber, $\mathrm{ADF}=$ acid detergent fiber, $\mathrm{GE}=$ gross energy, and $\mathrm{CP}=$ crude protein.

Table 5. Mineral compositions of winged bean tubers of ten accessions at Khon Kaen University in 2019.

\begin{tabular}{|c|c|c|c|c|c|c|c|c|c|c|c|c|c|}
\hline Accessions & $\begin{array}{c}N \\
(\%)\end{array}$ & $\begin{array}{c}P \\
(\%)\end{array}$ & $\underset{(\%)}{K}$ & $\begin{array}{l}\mathrm{Ca} \\
(\%)\end{array}$ & $\begin{array}{l}\mathrm{Mg} \\
(\%)\end{array}$ & $\begin{array}{c}\mathrm{S} \\
(\%)\end{array}$ & $\begin{array}{c}\mathrm{Fe} \\
(\mathrm{mg} / \mathrm{kg})\end{array}$ & $\underset{(\mathrm{mg} / \mathrm{kg})}{\mathrm{Mn}}$ & $\underset{(\mathrm{mg} / \mathrm{kg})}{\mathrm{Zn}}$ & $\underset{(\mathrm{mg} / \mathrm{kg})}{\mathrm{Cu}}$ & $\underset{(\mathrm{mg} / \mathrm{kg})}{\mathrm{Ni}}$ & $\begin{array}{c}\text { Co } \\
(\mathrm{mg} / \mathrm{kg})\end{array}$ & $\underset{(\mathrm{mg} / \mathrm{kg})}{B}$ \\
\hline W001 & $2.93 \mathrm{~b}$ & $0.32 \mathrm{~b}$ & $0.56 \mathrm{c}$ & $0.13 b$ & $0.29 \mathrm{~b}$ & $0.11 \mathrm{~b}$ & $105.19 \mathrm{a}$ & $23.27 \mathrm{c}$ & $20.58 \mathrm{e}$ & $10.62 \mathrm{c}$ & $2.06 \mathrm{c}$ & $0.26 \mathrm{~cd}$ & $42.63 \mathrm{a}$ \\
\hline W005 & $2.875 \mathrm{bc}$ & $0.26 \mathrm{e}$ & $0.53 \mathrm{~d}$ & $0.10 \mathrm{e}$ & $0.21 \mathrm{~g}$ & $0.10 \mathrm{c}$ & $77.85 \mathrm{~d}$ & $19.30 \mathrm{~d}$ & $22.78 \mathrm{~cd}$ & $5.06 \mathrm{e}$ & $2.03 \mathrm{c}$ & $0.22 \mathrm{ef}$ & $29.74 \mathrm{~d}$ \\
\hline W007 & $2.915 \mathrm{~b}$ & $0.30 c$ & $0.53 \mathrm{de}$ & $0.11 \mathrm{~d}$ & $0.25 \mathrm{de}$ & $0.09 \mathrm{~d}$ & $102.52 \mathrm{a}$ & $19.81 \mathrm{~d}$ & $28.25 \mathrm{~b}$ & $14.79 \mathrm{a}$ & $2.13 c$ & $0.22 \mathrm{ef}$ & $21.84 \mathrm{~g}$ \\
\hline W018 & $2.795 \mathrm{~d}$ & $0.29 \mathrm{~d}$ & $0.51 \mathrm{e}$ & $0.12 \mathrm{~b}$ & $0.31 \mathrm{a}$ & $0.11 \mathrm{~b}$ & $98.27 \mathrm{~b}$ & $24.08 \mathrm{c}$ & $15.32 \mathrm{~g}$ & $5.50 \mathrm{e}$ & $2.70 \mathrm{a}$ & $0.35 a$ & $27.86 \mathrm{e}$ \\
\hline W031 & $2.85 \mathrm{~cd}$ & $0.32 \mathrm{~b}$ & $0.59 \mathrm{~b}$ & $0.11 \mathrm{~d}$ & $0.27 \mathrm{c}$ & $0.11 \mathrm{~b}$ & $72.22 \mathrm{e}$ & $26.52 \mathrm{~b}$ & $18.28 \mathrm{f}$ & $11.39 \mathrm{~b}$ & $2.36 \mathrm{~b}$ & $0.30 \mathrm{~b}$ & $37.88 \mathrm{~b}$ \\
\hline W048 & $2.625 \mathrm{e}$ & $0.34 \mathrm{a}$ & $0.62 \mathrm{a}$ & $0.09 \mathrm{f}$ & $0.20 \mathrm{~h}$ & $0.09 \mathrm{~d}$ & $64.54 \mathrm{f}$ & $17.69 \mathrm{e}$ & $18.46 \mathrm{f}$ & $5.14 \mathrm{e}$ & $1.88 \mathrm{~d}$ & $0.21 \mathrm{f}$ & $36.46 \mathrm{c}$ \\
\hline W055 & $2.885 \mathrm{bc}$ & $0.32 \mathrm{~b}$ & $0.58 \mathrm{~b}$ & $0.12 \mathrm{c}$ & $0.24 \mathrm{e}$ & $0.10 \mathrm{c}$ & $71.05 \mathrm{e}$ & $20.25 \mathrm{~d}$ & $21.15 \mathrm{de}$ & $10.60 \mathrm{c}$ & $2.02 \mathrm{c}$ & $0.33 \mathrm{a}$ & $23.37 \mathrm{f}$ \\
\hline W061 & $3.51 \mathrm{a}$ & $0.32 \mathrm{~b}$ & $0.51 \mathrm{e}$ & $0.16 \mathrm{a}$ & $0.27 \mathrm{c}$ & $0.12 \mathrm{a}$ & $88.15 \mathrm{c}$ & $32.03 \mathrm{a}$ & $24.24 \mathrm{c}$ & $9.73 \mathrm{~d}$ & $2.31 \mathrm{~b}$ & $0.30 \mathrm{~b}$ & $27.74 \mathrm{e}$ \\
\hline W099 & $2.84 \mathrm{~cd}$ & $0.25 \mathrm{f}$ & $0.51 \mathrm{e}$ & $0.09 \mathrm{f}$ & $0.22 \mathrm{f}$ & $0.10 \mathrm{~cd}$ & $76.71 \mathrm{~d}$ & $24.18 \mathrm{c}$ & $19.54 \mathrm{ef}$ & $10.44 \mathrm{c}$ & $2.02 \mathrm{c}$ & $0.24 \mathrm{de}$ & $24.67 \mathrm{f}$ \\
\hline W148 & $2.475 \mathrm{f}$ & $0.30 \mathrm{c}$ & $0.53 \mathrm{~d}$ & $0.085 \mathrm{f}$ & $0.24 \mathrm{~d}$ & $0.09 \mathrm{~d}$ & $87.48 \mathrm{c}$ & $23.57 \mathrm{c}$ & $47.36 \mathrm{a}$ & $5.06 \mathrm{e}$ & $2.34 \mathrm{~b}$ & $0.28 \mathrm{bc}$ & $28.12 \mathrm{e}$ \\
\hline F-test & ** & ** & ** & ** & ** & $* *$ & ** & ** & ** & ** & $* *$ & ** & ** \\
\hline CV (\%) & 0.89 & 1.33 & 1.37 & 2.64 & 1.6 & 2.2 & 1.75 & 2.01 & 3.12 & 3.06 & 2.66 & 4.87 & 1.96 \\
\hline
\end{tabular}

The different letter after mean within column showed significant different. ** Significant at 0.01 probability level.

The following variabilities were observed in the mineral compositions of winged bean tubers: W001 produced the highest content of Fe $(105.19 \mathrm{mg} / \mathrm{kg})$ and B $(42.63 \mathrm{mg} / \mathrm{kg})$; W007 was highest in Fe as W001 $(102.52 \mathrm{mg} / \mathrm{kg})$ and $\mathrm{Cu}(14.79 \mathrm{mg} / \mathrm{kg}) ;$ W018 had the highest content of $\mathrm{Mg}(0.31 \%), \mathrm{Ni}(2.70 \mathrm{mg} / \mathrm{kg})$, and Co $(0.35 \mathrm{mg} / \mathrm{kg}) ;$ W048 produced the highest level of $\mathrm{P}(0.34 \%)$ and $\mathrm{K}(0.62 \%)$; W055 was highest in Co $(0.33 \mathrm{mg} / \mathrm{kg})$; W061 had the highest $\mathrm{N}(3.51 \%)$, Ca $(0.16 \%), \mathrm{S}(0.12 \%)$, and $\mathrm{Mn}(32.03 \mathrm{mg} / \mathrm{kg})$ contents; and W148 had the highest content of $\mathrm{Zn}(47.36 \mathrm{mg} / \mathrm{kg}$ ) (Table 5). The results indicate that each winged bean accession is a significant source of mineral composition, which further suggests its use as a nutritional supplement. 


\section{Discussion}

\subsection{Genotype Response and Environment}

This study investigated ten winged bean accessions of Thai and introduced sources sown into the Agronomy Field Crop Station, Faculty of Agriculture, Khon Kaen University, Khon Kaen, Thailand. Planting dates were determined by end of the rainfall, as high amounts of humidity and moisture cause plant stunning, as well as the occurrence of plant diseases [18]. In Thailand, bimodal rain creates two possible sowing dates: at the first drop of rain in June, and at the end of the rain season, mid-September to early October (Figure 2). A June planting may result in plant stress from pests, diseases, and water. Moreover, the winged bean plant is long-staying in the field typically until flowering, due to its photoperiod-sensitivity [13]. Within both periods of this study, all winged bean accessions were flowering on 17-22 November (data not shown).

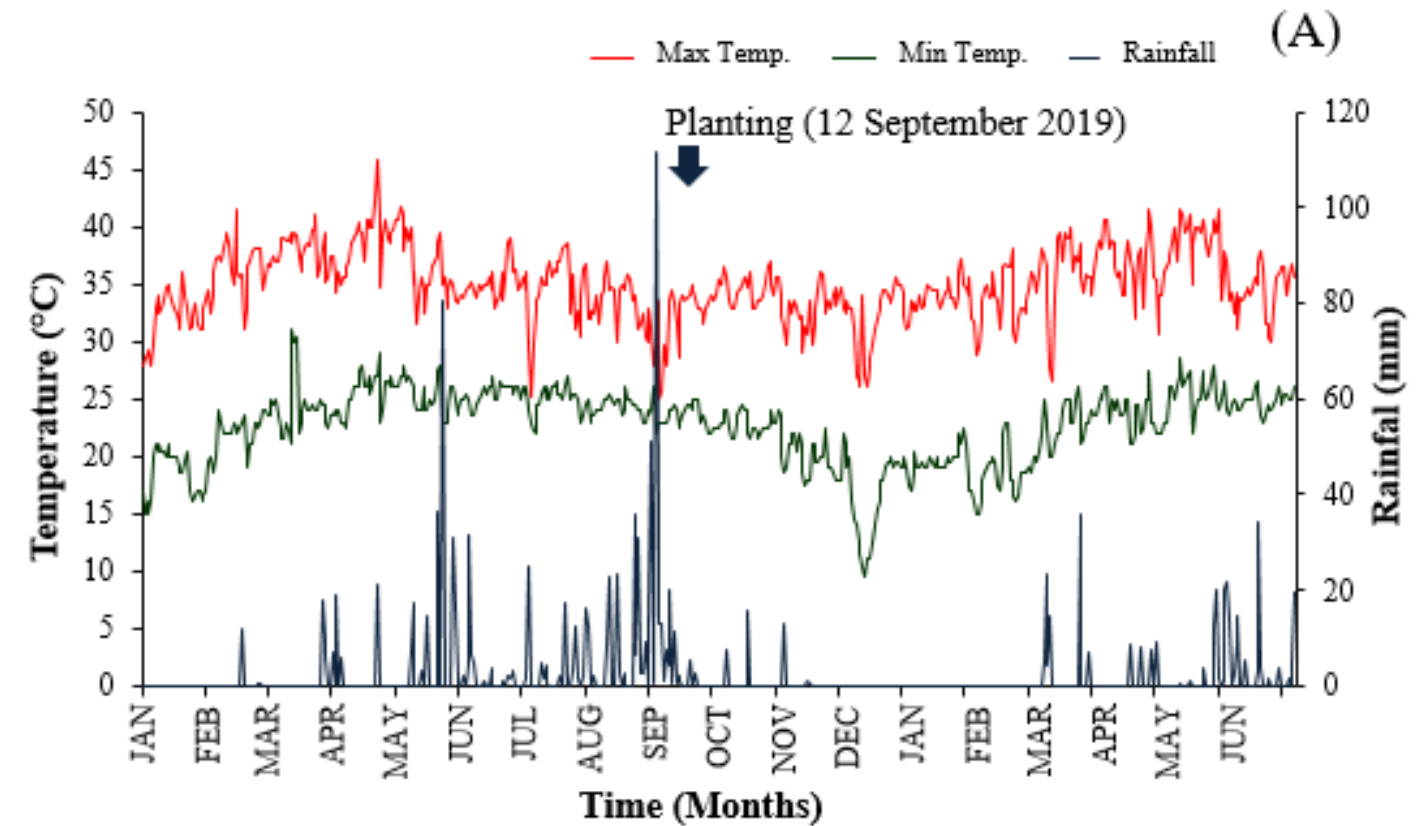

(B)

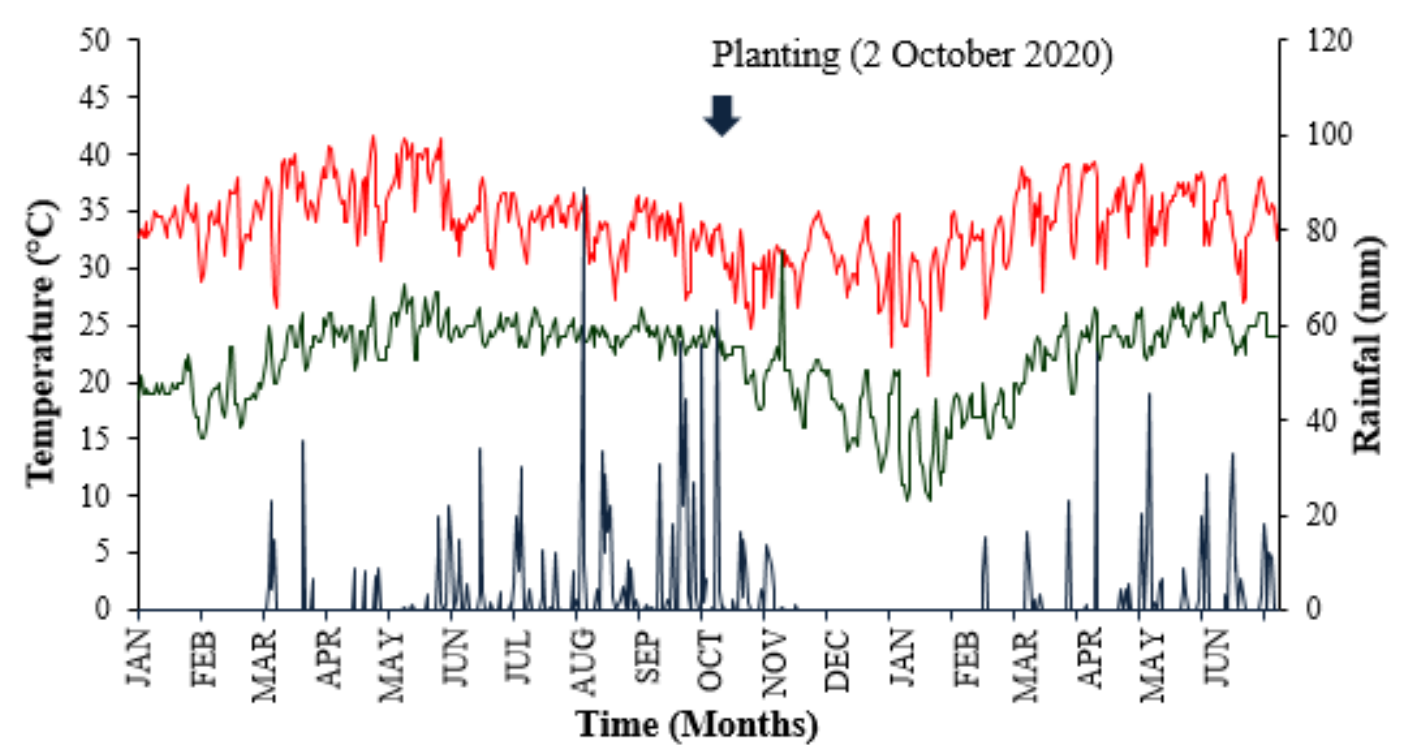

Figure 2. Average rainfall and the maximum and minimum temperatures during the 2019-2020 (A) and $2020-2021$ (B) experiments in Northeast Thailand (Khon Kaen). 
In the study, herein, pod yield of the winged bean was affected by year (Y), genotype $(\mathrm{G})$, and $\mathrm{Y} \times \mathrm{G}$ interaction, where $\mathrm{Y}$ was a major proportion of variation (Table 1). Our results agreed with those of Stephenson [19], in which a genotype by environment interaction (GxE) affected the yield of the winged bean. While $Y, G$, and $Y \times G$ affected pod yields, the two most consistent high pods yields were achieved by the W099 and W018 accessions (Table 2); which demonstrates their ability to grow in different environmental conditions. As mentioned earlier, Thailand has no genetic improvement program for the winged bean. The cultivars grown in Thailand are either landraces or selections from landraces with high pod yields and eating qualities. Varieties demonstrating the best yield performances typically result in their migration from place to place [12].

The total pod weights and number of pods were greater in the 2019 experiment versus those of the 2020 experiment, perhaps due to the longer duration of the vegetative phase, $66 \pm 3$ days and $48 \pm 2$ days, respectively. Other external factors affecting pod yield, particularly in the 2020 experiment, were insect pests, such as flower bud thrips (Megalurothrips sjostedti (Trybom)) and the bean pod borer (Maruca vitrata), which were a major cause of flower and pod defoliation, that further led to low pod numbers and pod weights in 2020 (Table 2). Khan [18] and Reddy [20]; reported that a wide range of insects belonging to Lepidoptera cause extensive flower damage, causing them to dry out and fall prematurely without forming pods. Infested pods are scarred and deformed which adhere to the flowers [21]. Control of flower bud thrips and the bean pod borer [22-27] is necessary for winged bean production before the insect appears. However, excessive use of chemicals on fresh pods is of major concern.

\subsection{Potential of Pod-Related Traits and Tuber Yield Production of the Winged Bean}

Fresh green pods are a major factor in the consumption of winged beans in Thailand and are evident by their green color, soft feel, and non-bitter taste [12]. Within the present study, all winged bean accessions were preliminarily selected for these traits before future yield trials were conducted (Table 6). Notably, both 10-pod weight and pod length (63.03 to $71.67 \mathrm{~g}$ and 13.79 to $13.89 \mathrm{~cm}$, respectively) were not characteristic variables (Tables 1 and 2), as they are considered proximate norms within the Thai winged bean marketplace.

Table 6. The origins and sources of the ten selected winged beans used in this study.

\begin{tabular}{cccc}
\hline Accessions No & Accessions Code & Fresh Pod Characters & Original and Sources \\
\hline 1 & W001 & Green color, non-bitter, short, and soft & Japan: Gene bank of NIAS-Japan \\
2 & W005 & Green color, non-bitter, short, and soft & $\begin{array}{c}\text { Indonesia: Gene bank of NIAS-Japan } \\
3\end{array}$ \\
W007 & Green color, non-bitter, short, and soft & Indonesia: Gene bank of NIAS-Japan \\
4 & W018 & Green color, non-bitter, short, and soft & Nigeria: Gene bank of NIAS-Japan \\
5 & W031 & Green color, non-bitter, short, and soft & Nigeria: Gene bank of NIAS-Japan \\
6 & W048 & Green color, non-bitter, short, and soft & Malaysia: Gene bank of NIAS-Japan \\
7 & W055 & Green color, non-bitter, short, and soft & Khon Kaen, Thailand \\
8 & W061 & Green color, non-bitter, short, and soft & Nakhon Si Thammarat, Thailand \\
9 & W099 & Green color, non-bitter, short, and soft & Nan, Thailand \\
10 & W148 & Green color, non-bitter, short, and soft & Trang, Thailand \\
\hline
\end{tabular}

Winged bean production includes a sensitive photoperiod that limits year-round production causing a fluctuation in the prices of the winged bean. Growers normally sow winged bean seeds at the beginning of the rainy season (the first or second rain in a bimodal rain system). The plant typically flowers in October through November, creating a two to three-month harvest. Pod production then decreases in March. Upon the completion of the harvest, the plant dries, summer leaf defoliation takes place, and growers no longer attempt irrigation, as pods are no longer produced. Any remaining winged bean plants and tubers are utilized only as cover crops or tilled into the soil as manure.

As mentioned earlier, only some villages in the Photharam District, Ratchaburi province of Thailand establish and promote the consumption of winged bean tubers. Because tuber yields are only achieved after digging up the plant, these farmers sow 
winged bean seeds from July to August and harvest the tubers once at six months after planting, from January to February [13]. Tubers are cut, washed, and then boiled at least for two hours. Boiled winged bean tubers can fetch a price of up to USD $60 \mathrm{per} \mathrm{Kg}$. However, the winged bean tuber's popularity remains fixed in other areas of Southeast Asia, like Papua New Guinea and Myanmar [13].

As the first known study of winged bean tuber yield in Thailand, our results demonstrated that some winged bean accession gave a tuber yield of more than $15 \mathrm{~T} / \mathrm{ha}$ (Table 3), significantly higher than the $11.7 \mathrm{~T} /$ ha peak yield reported by Khan [28]. Our two winged bean accessions, W018 and W099, were consistent highest in tuber yield (Table 3), total pod weight, and the number of pods (Table 2). Additionally, only some accessions are capable of producing tubers $[14,29,30]$. Moreover, few accessions have been regarded as high in pod and tuber yields, or 'dual-purpose' [13]. The W018 and W099 winged bean accessions produced successful pod and tuber yields, are consequently classified as dual-purpose winged accessions. However, before recommending these accessions to winged bean growers throughout the country, a multi-location yield trial is required.

\subsection{Proximate Analysis of Nutrients and Minerals of Winged Bean Tuber}

Interestingly, the nutrient content analysis in the present study shows high protein contents of up to $25.59 \%$ (W061) (Table 4). The previous study by Adegboyega [15] reported that the winged bean accession Tpt42 contained 19.07\% tuber protein. The W099 and W018 accessions herein produced tuber protein contents of $20.92 \%$ and $21.04 \%$, respectively (Table 4), which are higher than those of typical tuber crops, like cassava [31,32]. Our study also considered the fiber, energy, and minerals contents of the winged bean tubers (Tables 4 and 5).

Because of the low consumption and utilization of winged bean tubers in Thailand, alternative uses, such as feed material for livestock may also be considered. Recent results on the potential of winged bean production have provided a framework for continued study into the usefulness of the winged bean as an alternative crop for staple food and feed, particularly within low input cropping systems in the tropics and subtropics as food-feed production systems [17]. The variation and high amounts of nutrient and mineral contents in winged bean tubers suggest its potential as food security and nutritional modification in tropical agriculture [15].

\section{Materials and Methods}

\subsection{Plant Material}

Ten accessions of winged bean (P. tetragonolobus (L.) DC) were used in this study. Six accessions were obtained from introduced sources from the Gene bank of NIAS-Japan provided by Dr. Prakit Somta, Kasetsart University, Thailand and four accessions were obtained locally in Thailand (Table 6). All accessions were grown in 2019 and 2020 for genetic diversity study in the Agronomy Field Crop Station, Khon Kaen University, Khon Kaen, Thailand. A visual selection of young pod characteristics, such as pod number, softness, color, and non-bitter taste was conducted.

\subsection{Field Experiment}

The 10 winged bean accessions were laid out in a randomized complete block design (RCBD) with three replications at Khon Kaen University's Agronomy Field Crop Station, Faculty of Agriculture from September 2019 to March 2020 and from October 2020 to April 2021. The experimental plots were $5 \times 1 \mathrm{~m}$, spaced $1 \mathrm{~m}$ between rows and $0.5 \mathrm{~m}$ between plants, totaling ten plants per plot, with a distance of $2 \mathrm{~m}$ between plots within each row. A $2 \mathrm{~m}$ high net constructed of bamboo and nylon was used for support. Fertilizer was initially applied at the rate of $14.06 \mathrm{~kg} / \mathrm{ha}\left(\mathrm{N}_{2}-\mathrm{P}_{2} \mathrm{O}_{5}-\mathrm{K}_{2} \mathrm{O}\right)$ at 21 days after planting (DAP). A second fertilizer application was applied at the rate of $18.75 \mathrm{kgN}_{2} / \mathrm{ha}, 37.50 \mathrm{kgP}_{2} \mathrm{O}_{5} / \mathrm{ha}$, and $18.75 \mathrm{kgK}_{2} \mathrm{O} / \mathrm{ha}$ at two months of age. Manual weed control was practiced regularly 
during the growing period. Plants were watered regularly, and disease and pest control were conducted as required throughout the growing period.

\subsection{Data Collection}

Data including total pod weight (g), number of pods, 10-pod weight (g), and pod length $(\mathrm{cm})$ were recorded. Pod-related traits were recorded at three-day intervals during the two months of pod production. Tuber weights were recorded at eight months. Tubers were removed from the plant, and their fresh weights were immediately recorded. The fresh tubers of the winged bean accessions in each plot (approximately ten tubers) were immediately sub-sampled, washed in tap water, and then sliced into small chips and oven-dried at $50-55^{\circ} \mathrm{C}$ for $48 \mathrm{~h}$, or until a constant weight was achieved via a tray drier (EQ-04SW, Leehwa Industry Company, Kyongbuk, Korea). The chipped samples were ground into a powder with a grinder (Standard EM-11, Sharp Thai Company Limited, Bangkok, Thailand). The powdered samples were then sieved through a $1.0 \mathrm{~mm}$ mesh screen that helped to ensure that the sample for chemical analysis was representative. The samples were later used for laboratory analyses.

Nutritional analysis was performed at the Animal Nutrition Unit, Department of Animal Science, Khon Kaen University, Khon Kaen, Thailand.

Crude fat or ether extract (EE), crude fiber $(\mathrm{CF})$, and ash were determined by the Weende method according to the AOAC [33] with slightly modified were briefly described below.

Determination of EE: the $5.0 \mathrm{~g}$ powdered sample was extracted in $100 \mathrm{~mL}$ diethyl ether and shaken it for $24 \mathrm{~h}$ in an orbital shaker. The filtrate was collected in the same flask after it was equilibrated with $100 \mathrm{~mL}$ diethyl ether and again shaken for $24 \mathrm{~h}$. The ether was dried in an oven at $60^{\circ} \mathrm{C}$ for $30 \mathrm{~min}$ after being concentrated to dryness in a steam bath. The weight of ether extract was determined by difference and calculated as a percentage of the weight of sample analyzed [34] thus:

$$
\text { Crude fat }(\%)=\frac{\text { Weight of flask with fat }- \text { weight of empty flask }}{\text { Weight of sample }} \times 100
$$

Determination of CF: the $5.0 \mathrm{~g}$ powdered sample was processed with $100 \mathrm{~mL}$ of $1.25 \%$ $\mathrm{H}_{2} \mathrm{SO}_{4}$ for half an hour and filtered with pressure. The remaining residue was then washed with hot water. This process was repeated on the residue by using $100 \mathrm{~mL}$ of $1.25 \% \mathrm{NaOH}$ sol. The remaining filtrate was dried at $100^{\circ} \mathrm{C}$. It was subsequently incinerated in a muffle furnace at $550{ }^{\circ} \mathrm{C}$ for $5 \mathrm{~h}$. The weight of the fiber was determined by difference and calculated as a percentage of the weight of sample analyzed [35] thus:

Crude fiber $(\%)=\frac{\text { (Weight of crucible }+ \text { Ash })- \text { Weight of crucible+sample after washing, boiling and drying }}{\text { Weight of sample }} \times 100$

Determination of ash: A porcelain crucible was dried at $105^{\circ} \mathrm{C}$ for $1 \mathrm{~h}$, and then the $5.0 \mathrm{~g}$ of powdered sample was placed in the crucible. The crucible with plant samples was ashed first at $250{ }^{\circ} \mathrm{C}$ for an hour, followed by ashing at $550{ }^{\circ} \mathrm{C}$ for five hours in a muffle heating system. The sample was then cooled in a desiccator. The weight of the ash obtained was determined by difference and calculated as a percentage of the weight of sample analyzed [35] thus:

$$
\text { Ash }(\%)=\frac{(\text { Weight of crucible }+ \text { Ash })-\text { Weight }(g) \text { of empty crucible }}{\text { Weight of sample }} \times 100
$$

Crude protein $(\mathrm{CP})$ was determined via the Kjeldahl method according to the AOAC [33] as well. Briefly, about $10 \mathrm{~g}$ of potassium sulfate and $0.5 \mathrm{~g}$ of copper sulfate were added to flask $25 \mathrm{~mL}$ of concentrated sulfuric acid was added. The flask was plays on digestion chamber and heated gently to boil until contents were clear and allowed the liquid to cool and diluted with $200 \mathrm{~mL}$ of distilled until all ammonia was passed over and was received over standard sulfuric acid, which was then back titrated with standard $\mathrm{NaOH}$ in order 
to determine the amount of standard acid used to neutralize the ammonia evolved from digested material. Similarly, a blank sample was run.

$$
\begin{gathered}
\text { Total nitrogen }(\%)=\frac{1.4(\mathrm{~B}-\mathrm{A}) \mathrm{N}}{\text { Weight of sample }} \\
\text { Crude protein }=\text { total nitrogen } \times 6.25
\end{gathered}
$$

where, $\mathrm{B}=$ volume of $\mathrm{N} / 10 \mathrm{NaOH}$ for blank, $\mathrm{A}=$ volume of $\mathrm{N} / 10 \mathrm{NaOH}$ used for sample, and $\mathrm{N}=$ normality of standard $\mathrm{NaOH}$.

Neutral detergent fiber (NDF) and acid detergent fiber (ADF) contents were determined by detergent analysis according to Van Soest [36].

NDF was calculated using the following formula,

$\operatorname{NDF}(\%)=\frac{\text { (Weight of crucible }+ \text { Fiber content })- \text { Weight of empty cricible }}{\text { Weight of sample }} \times 100$

ADF was calculated using the following formula,

$$
\operatorname{ADF}(\%)=\frac{\text { Weight of crucible }+ \text { Fiber content }}{\text { Weight of sample }} \times 100
$$

An automatic adiabatic bomb calorimeter (AC500, Leco, St. Joseph, MI, USA) was used for gross energy (GE) estimation. Additionally, the nutrient contents of the winged bean tubers were determined. Atomic absorption spectrophotometry was employed to determine concentrations of total $\mathrm{P}, \mathrm{K}, \mathrm{Ca}, \mathrm{Mg}, \mathrm{Fe}, \mathrm{Cu}, \mathrm{Zn}, \mathrm{Ni}, \mathrm{B}$, and $\mathrm{Co}$ through wet digestion (nitric-perchloric acid digestion) [37]. In brief, $5 \mathrm{~mL}$ of $65 \% \mathrm{HNO}_{3}$ was added to the sample, and then the mixture was boiled gently for 30-45 min. After cooling, $2.5 \mathrm{~mL}$ of $70 \% \mathrm{HClO}_{4}$ was added, and the mixture was gently boiled until dense white fumes appeared. Later, the mixture was allowed to cool, and $10 \mathrm{~mL}$ of deionized water was added followed by further boiling until the fumes were totally released [37]. Total $\mathrm{N}$ was determined via Kjeldahl method [33] as formula (4) and total sulfur through turbidimetry. Briefly, $3 \mathrm{~mL}$ of concentrated nitric acid was added to the samples or standards ( $0.5 \mathrm{~g})$, the samples were left to stand for $15 \mathrm{~min}$ before closing the Teflon vessels and proceeding to digestion in the microwave oven. At the end of digestion, the vessel was cooled until a pressure of about $69 \mathrm{kPa}$ was reached, then the lid was carefully removed. Next, the volume was adjusted to $50 \mathrm{~mL}$ with deionized water and S was quantified by ICP-AES [38].

\subsection{Data Analysis}

Data were analyzed using Statistix 10 of variance (ANOVA), and combined analysis was also performed. A least significant difference (LSD) at $p<0.05$ was carried out for mean comparisons on the parameters measured among all accessions.

\section{Conclusions}

Ten winged bean accessions were preliminarily evaluated across two production years for potential in pod and tuber yield as well as protein and nutritional content, referred to here as dual-purpose. The two accessions out of those, W099 and W018 were identified as high potential accessions for the two traits which are able to be source of food and feed stuff. However, further evaluation under diverse environments will depict availability of accession through the country.

Author Contributions: Conceptualization, S.S. and S.C.; methodology, S.S.; software, S.S.; validation, T.M., S.C. and J.S.; formal analysis, S.S.; investigation, S.C.; resources, S.C.; T.M. and J.S.; data curation, S.S.; writing - original draft preparation, S.C.; writing-review and editing, S.C.; visualization, T.M.; supervision, S.C.; project administration, S.C.; funding acquisition, S.J. All authors have read and agreed to the published version of this manuscript.

Funding: This research received no external funding. 
Institutional Review Board Statement: Not applicable.

Informed Consent Statement: Not applicable.

Data Availability Statement: The data presented in this study are available on request from the corresponding author.

Acknowledgments: This research was supported by The Plant Breeding Research Center for Sustainable Agriculture, Khon Kaen University and The Thailand Research Fund, providing financial support through the Senior Research Scholar Project of Sanun Jogloy (Project No. RTA6180002).

Conflicts of Interest: The authors declare no conflict of interest.

\section{References}

1. Harder, D.K. Chromosome Counts in Psophocarpus. Kew Bull. 1992, 47, 529-534. [CrossRef]

2. Kuswanto, A.N.; Saptadi, D.; Waluyo, B. Evaluation and Selection on Local Strains of Winged Bean in Brawijaya University Indonesia. Trans. Persat. Genet. Malays. 2016, 3, 51-55.

3. NAS. Underexploited Tropical Plants with Promising Economic Value; Board of Science and Technology for International Development; National Academy of Sciences: Washington, DC, USA, 1975; pp. 56-63.

4. Lepcha, P.; Egan, A.N.; Doyle, J.J.; Sathyanarayana, N. A Review on Current Status and Future Prospects of Winged Bean (Psophocarpus tetragonolobus) in Tropical Agriculture. Plant Foods Hum. Nutr. 2017, 72, 225-235. [CrossRef] [PubMed]

5. Mohanty, C.S.; Verma, S.; Singh, V.; Khan, S.; Gaur, P.; Gupta, P.; Nizar, M.A.; Dikshit, N.; Pattanayak, R.; Shukla, A.; et al. Characterization of winged bean (Psophocarpus tetragonolobus (L.) DC.) based on molecular, chemical, and physiological parameters. Am. J. Mol. Biol. 2013, 3, 187-197. [CrossRef]

6. NAS. The Winged Bean: High-Protein Crop for the Humid Tropics, 2nd ed.; National Academy Press: Washington, DC, USA, 1981; p. 41.

7. Amoo, I.A.; Adebayo, O.T.; Oyeleye, A.O. Chemical evaluation of Winged beans (Psophocarpus tetragonolobus), pitanga cherries (Eugenia uniflora) and orchid fruit (Orchidfruit myristica). Afr. J. Food Agric. Nutr. Dev. 2006, 6, 1-12.

8. Kadam, S.S.; Salunkhe, D.K.; Luh, B.S. Winged bean in human nutrition. Crit. Rev. Food Sci. Nutr. 1984, 21, 1-40. [CrossRef]

9. Prakash, D.; Misra, P.N.; Misra, P.S. Amino acid profile of winged bean (Psophocarpus tetragonolobus (L.) DC): A rich source of vegetable protein. Plant Foods Hum. Nutr. 1987, 37, 261-264. [CrossRef] [PubMed]

10. Adegboyega, T.T.; Abberton, M.T.; AbdelGadir, A.A.H.; Dianda, M.; Maziya-Dixon, B.; Oyatomi, O.A.; Ofodile, S.; Babalola, O.O. Nutrient and antinutrient composition of winged bean (Psophocarpus tetragonolobus (L.) DC.) seeds and tubers. J. Food Qual. 2019, 2019, e3075208. [CrossRef]

11. Mahto, C.S.; Dua, R.P. Genetic Divergence for Yield Contributing Traits in Winged Bean. Indian J. Plant Genet. Resour. 2009, 22, 239-242.

12. Laosatit, K.; Amkul, K.; Chankaew, S.; Somta, P. Molecular genetic diversity of winged bean (Psophocarpus tetragonolobus (L.) DC.) gene pool in Thailand assessed by SSR markers. Hort. Plant J. 2021. [CrossRef]

13. Eagleton, G.E. Winged bean (Psophocarpus tetragonolobus) cropping systems. Biodiversitas 2020, 21, 5927-5946. [CrossRef]

14. Hildebrand, D.F.; Chaven, C.; Hymowitz, T.; Bryan, H.H. Variation in storage root protein content in winged beans, Psophocarpus tetragonolobus (L.) DC. Trop. Agric. 1982, 59, 59-61.

15. Alexandratos, N.; Bruinsma, J. World Agriculture towards 2030/2050 the 2012 Revision; Food Agric. Organ UN: Rome, Italy, 2012; p. 146. [CrossRef]

16. Thornton, P.K. Livestock production: Recent trends, future prospects. Philos. Trans. R. Soc. Lond. B Biol. Sci. 2010, 365, $2853-2867$. [CrossRef] [PubMed]

17. Wanapat, M. Potential uses of local feed resources for ruminants. Trop. Anim. Health Prod. 2009, 41, 1035-1049. [CrossRef] [PubMed]

18. Khan, T. Winged Bean Production in the Tropics; Food and Agriculture Organization of the United Nations: Rome, Italy, 1982; pp. 195-217.

19. Stephenson, R.A.; Kesavan, V.; Claydon, A.; Bala, A.A.; Kaiulo, J.V. Studies on Tuber Production in Winged Bean (Psophocarpus tetragonolobus (L.) DC.). In Proceedings of the Fifth International Symposium on Tropical Root and Tuber Crops International Society of Tropical Root Crops, PCARR, Los Baños, Philippines, 17-21 September 1979.

20. Reddy, P.P. Tropical Root and Tuber Crops: An Overview. In Plant Protection in Tropical Root and Tuber Crops; Springer: New Delhi, India, 2015; pp. 1-15. [CrossRef]

21. Srinivasan, R. Insect and Mite Pests on Vegetable Legumes: A Field Guide for Identification and Management; AVRDC-The World Vegetable Center: Shanhua, Taiwan, 2014; 92p.

22. Afun, J.V.K.; Jackai, L.E.N.; Hodgson, C.J. Calender and monitored insecticide application for the control of cowpea pests. Crop Prot. 1991, 10, 363-370. [CrossRef]

23. Oparaeke, A.M. The sensitivity of flower bud thrips, Megalurothrips sjostedti Trybom (Thysanoptera: Thripidae), on cowpea to three concentrations and spraying schedules of Piper guineense Schum. \& Thonn. extracts. Plant Protect. Sci. 2006, 42, 106-111. [CrossRef] 
24. Muthomi, J.W.; Otieno, P.E.; Cheminingwa, G.N.; Nderitu, J.H.; Wagacha, J.M. Effect of chemical spray on insect pests and yield quality of food grain legumes. J. Entomol. 2008, 3, 156-163. [CrossRef]

25. Regmi, R.; Tiwari, S.; Thapa, R.B.; Fashions, G.B.K.C. Ecofriendly management of spotted pod borer, Maruca vitrata on yardlong bean in Chitwan, Nepal. Inter. J. Res. 2014, 1, 386-394.

26. Aktar, S.; Uddin, M.M.; Ahmed, K.S. Bioefficacy of some novel insecticides and biopesticides for managing bean pod borer, Maruca vitrata Geyer. J. Bangladesh Agril. Univ. 2020, 18, 183-188. [CrossRef]

27. Ahmed, R.N.; Uddin, M.M.; Haque, M.A.; Ahmed, K.S. Field evaluation of microbial derivatives for management of legume pod borer, Maruca vitrata F. in yard long bean. J. Entomol. Zool. Stud. 2020, 8, 162-166. [CrossRef]

28. Khan, T.N.; Bohn, J.C.; Stephenson, R.A. Winged beans: Cultivation in Papua New Guinea. World Crop. Livest. 1977, 29, 208-214.

29. Khan, T.N.; Erskine, W. The adaptation of winged bean (Psophocarpus tetragonolobus (L.) DC.) in Papua New Guinea. Aust. J. Agric. Res. 1978, 29, 281-289. [CrossRef]

30. Erskine, W.; Khan, T.N. Variation within and between land races of winged bean (Psophocarpus tetragonolobus (L.) DC.). Field Crops Res. 1980, 3, 359-364. [CrossRef]

31. Shewry, R.P. Tuber Storage Proteins. Ann. Bot. 2003, 91, 755-769. [CrossRef]

32. Morgan, N.K.; Choct, M. Cassava: Nutrient composition and nutritive value in poultry diets. Anim. Nutr. 2016, 2, $253-261$. [CrossRef]

33. AOAC. Official Methods of Analysis, 15th ed.; The Association of Official Analytical Chemists (AOAC): Arlington, VA, USA, 1991.

34. Adamu, H.M.; Ushie, O.A.; Gwangwala, A.H.; Yadav, R.P.; Singh, A.; Bhardwaj, A.K.; Lone, P.A.; Dar, M.M.; Parray, J.A.; Shah, K.; et al. Estimation of Total Flavonoids and Tannins in the Stem Bark and Leaves of Anogeisus leiocarpus Plant plant. Int. J. Tradit. Nat. Med. 2013, 2, 141-148.

35. Sigel, H. Metals in Biological Systems; Marcel Dekker: New York, NY, USA, 1978.

36. Van Soest, P.J.; Robertson, J.D.; Lewis, B.A. Methods for dietary fiber, neutral detergent fiber and non-starch polysaccharide in relation to animal nutrition. J. Dairy Sci. 1991, 74, 3583-3597. [CrossRef]

37. Hseu, Z.Y. Evaluating heavy metal contents in nine composts using four digestion methods. Bioresour. Technol. 2004, 5, 53-59. [CrossRef]

38. Rossete, A.L.R.M.; Bendassolli, J.A.; Trivelin, P.C.O. Organic sulfur oxidation to sulfate in soil samples for total sulfur determination by turbidimetry. Rev. Bras. Ciência Solo 2008, 32, 2547-2553. [CrossRef] 